\title{
The effects of reforming
}

regulation in resolving

\section{insolvency towards EODB rank} improvement: Evidence from Indonesia

by M Hadi Shubhan

Submission date: 13-Aug-2020 02:19PM (UTC+0800)

Submission ID: 1369066462

File name: hadi-The_effects_of_reforming_regulation_in_resolving.pdf (1.33M)

Word count: 8982

Character count: 48148 


\section{The effects of reforming regulation in resolving insolvency towards EODB rank improvement: Evidence from Indonesia}

\section{Hadi Shubhan}

25 nesian Bankruptcy Law Study, Faculty of Law, Airlangga University, Surabaya, Indonesia

\section{Correspondence}

M. Hadi Shubhan 2 donesian Bankruptcy Law, Faculty of Law, Airlangga University, Surabaya, Indonesia.

Email: hadi@fh.unair.ac.id

\begin{abstract}
This article examines the effectiveness of policy reform and implementation in resolving insolvency in Indonesia. The Ease of Doing Business (EODB) in Indonesia has significantly increased over the last 6 years, from ranking 129th in 2012 to 73rd in 2019. Among the 10 EODB indicators, resolving insolvency was identified to be the highest contributing indicator. In 2019, this indicator ranked 36th-far above the overall aforementioned Indonesian EODB score, a 73rd worldwide ranking. This article examines the factors leading to a high bankruptcy settlement score as well as the indicators that must be improved to raise Indonesia's EODB ranking.
\end{abstract}

\section{INTRODUCTION}

Following the 1997 Asian Financial Crisis, the comparative stability of the New Order ended upon President Suharto's forced resignation in May 1998 after 32 years in office. ${ }^{1}$ This led to political and state reform that drastically changed numerous aspects of the economic and legal order. In the words of Nonet and Selznick regarding post-1998 policy reform, ${ }^{2}$ many of the changes led to a more responsive and autonomous legal system compared to the one during the New $\mathrm{Order}^{3}$ and Old Order ${ }^{4}$ regimes, which consisted of repressive laws.

The Bankruptcy Law was a notable policy implemented by the Indonesian government to promote much-needed economic reform. Furthermore, outdated government rules and regulations (i.e., in the area of company law) were gradually being replaced with laws which were more suitable for the country's rapidly globalising economy. This bankruptcy policy reform 
fundamentally changed the principles of bankruptcy and bankruptcy settlement. ${ }^{5}$ Indonesia has implemented two bankruptcy policy reforms thus far; the first with the issuance of Law No. 4 of 1998 and then with the issuance of Law No. 37 of 2004. Both laws have progressively changed the basic concepts, philosophies, and principles of previously applied bankruptcy laws. Despite this, the view of David Linnan is that Law No. 37/2004 still contains two basic insolvency approaches that reach back to the Dutch law origins of the Indonesian framework, notably liquidation in bankruptcy and a weak voluntary debt compromise procedure. ${ }^{6}$

Such policy reform, nevertheless, is highly effective in bankruptcy settlement and bankruptcy asset management. Before 1998, for a period of approximately 50 years since Indonesia's independence ${ }_{3}$ only a few bankruptcy cases were filed. According to a law firm, there were nearly zero bankruptcy declarations pronounced by the courts in Jakarta over the past 20 years. ${ }^{7}$ Darminto Hartono remarked that, prior to 1998 , bankruptcy law simply did not exist for all practical purposes; and debt settlements or reorganisations were treated as business matters and reconciled via negotiation and out-of-court settlements. ${ }^{8}$ Research indicates that approximately 130 cases have been filed domestically; in 2019 alone, a total of 549 bankruptcy requests were made in commercial courts nationwide. ${ }^{9}$ This equates to a national average of one bankruptcy case a year.

Moreover, the spike in the handling of bankru 23 was especially apparent in two particular bankruptcy courts (i.e., the commercial courts in Central Jakarta District Court and in Surabaya District Court). The Commercial Court of Central Jakarta handled 100 cases in 1999 and this skyrocketed to 230 cases in 2017. Meanwhile, the Commercial Court of Surabaya also handled 230 cases in the same year. The number of cases filed more than doubled after the implementation of the bankruptcy policy reform. The comparison between the average number of bankruptcy cases filed domestically before and after the bankruptcy policy reform is shown in Table 1.

Owing to this reform, the management of bankruptcy asset settlement after a debtor declares bankruptcy has also become more efficient and effective. Prior to these reforms, settlements made in bankruptcy asset management could drag on for decades. For instance, the bankruptcy case of PT. Arafat has taken decades; in fact, the supervising judge has already been changed four times and the case has not yet been settled to date. Following bankruptcy law reforms, the 3 erage settlement made in bankrupt asset management takes an average of 3 years. ${ }^{10}$ The new Bankruptcy Law provides for "a definite time frame for decision-making on a declaration of bankruptcy" which is aimed at speeding up bankruptcy proceedings. ${ }^{11}$

The more effective, efficient, and legally sound settlement of a bankruptcy proposal and bankruptcy asset management is essential to the business world. Creditors hold an interest in the certainty of the return of receivables from debtors, including the certainty of execution against items of collateral. On the other hand, the debtors' primary concern is to immediately resolve issues with the payment of debt obligations using their assets, so that they can return to

T A B LE 1 The case comparison before and after Bankruptcy Law Reform

\begin{tabular}{ll} 
Period & Average annual number of bankruptcy cases filed \\
\hline Before 1998 & 1 case (throughout Indonesia) \\
1999 & 100 cases (only in one district court, Commercial Court in Central Jakarta District Court) \\
\hline 2019 & 336 cases (only in one district court, Commercial Court in Central Jakarta District Court) \\
\hline Source: Commercial Court in Central Jakarta District Court.
\end{tabular}


T A B LE 2 Individual EODB indicator rankings from 2016 to 2019

\begin{tabular}{|c|c|c|c|c|}
\hline EODB indicators & 2016 & 2017 & 2018 & 2019 \\
\hline Starting a business & 167 & 151 & 144 & 134 \\
\hline Dealing with construction permits & 113 & 116 & 108 & 112 \\
\hline Registering property & 123 & 118 & 106 & 100 \\
\hline Getting electricity & 61 & 49 & 38 & 33 \\
\hline Paying taxes & 115 & 104 & 114 & 112 \\
\hline Getting credit & 70 & 62 & 55 & 44 \\
\hline Protecting investors & 69 & 70 & 43 & 51 \\
\hline Trading across borders & 113 & 108 & 112 & 116 \\
\hline Enforcing contracts & 171 & 166 & 145 & 146 \\
\hline Resolving insolvency & 74 & 76 & 38 & 36 \\
\hline
\end{tabular}

Source: World Bank.

business. Employees prioritise career continuity and job security, whereas the government prioritises tax certainty, licensing certainty and employment certainty, among other things.

Given the correlation between bankruptcy settlement and the business world, bankruptcy was included by the ${ }_{8}$ World Bank as one of the EODB indicators. EODB defines 10 quantitative indicators, namely starting a business, dealing with construction permits, registering property, paying taxes, getting credit, enforcing contracts, getting electricity, trading across borders, resolving insolvency and protecting minority investors. Over the past 6 years, EODB in Indonesia has drastically improved from being on the 129th ranking in 2012 to the 73rd ranking in 2019. This ranking increase is inextricably linked to Indonesia's excellent bankruptcy settlement score. Separately, the bankruptcy settlement indicator went up from the 85th position in 2012 to the 36th in 2019. It is the most significant contributor among the 10 indicators (see in Table 2).

The substantial rank increase of the resolving insolvency indicator is inseparable from bankruptcy law reforms and their enforcement. The present research is required to examine the measures taken by the government to achieve such growth in the bankruptcy settlement indicator, lessons learned from this phenomenon and factors that continue to hamper an even more progressive increase in this specific indicator.

\section{2 | THE INDONESIAN BANKRUPTCY POLICY FRAMEWORK}

\section{1 | Background insolvency regulation}

The bankruptcy institution in Indonesia was established during the Dutch East Indies era and is regulated by the Verification of the Faillissement en Surseance van Betaling de Europeanen in Netherlands Indie (Faillisement Verordening/FV) and the Staatsblad 1905 Number 217 in conjunction with Staatsblad 1906 Number 348. Based on the regulation that states the enactment of the Bankruptcy Regulations (Staatsblad 1906 Number 348), the Bankruptcy Regulations came into force on November 1, 1906. This brought about the revocation of certain provisions, 
including the entire third book of the Commercial Law (Kitab Undang-Undang Hukum Dagang/KUHD) along with some of its previous regulations.

Although the Faillisement Verordening (Bankruptcy Actit (S. 1905-217) was the prevailing law, it was rarely put into practice. Based on data from the National Law Development Agency (Badan Pembinaan Hukum Nasional/BPHN), bankruptcy declaration decisions between 1950 and 1996 only amounted to approximately 130 decisions. ${ }^{12}$ This number suggests that only a few legal subjects used this bankruptcy instrument and there were several explanations behind why it was rarely used. One primary reason was that the bankruptcy procedure and settlement were excessively complicated and tedious-and the bankruptcy case of PT. Arafat is a testament to this. ${ }^{13}$

According to former Commissioner Judge, Paulus Efendi Lotulung, the bankruptcy case of PT. Arafat took decades, with even the commissioner judges changing four times. To date, the case has not yet been settled. ${ }^{14}$ Another reason was that bankruptcy assets were not maximised by the Civil Servant Insolvency Administrators of the Balai Harta Peninggalan (BHP), which was the only bankruptcy receiver (kurator) at the time. Sudargo Gautama illustrated that there were many bankruptcy cases that had to be raised again because they deemed these objects as inadequate (opgegeven wegens gebrek aan baten) after examining whether the people who had been declared bankrupt still had remaining assets. ${ }^{15}$ Apparently, this was a major hindrance for creditors to choose bankruptcy statements.

The difficulty of filing a bankruptcy application is compounded by the difficulty of managing and settling bankruptcy assets due to the antiquated legal system of the Bankruptcy Regulations inherited from the Dutch colonialists. These regulations only acknowledged one type of bankruptcy receiver, namely the Civil Servant Insolvency Administrators (BHP). The provisions stipulating that curation could only be performed by the BHP were exactly what hindered the process of bankrupt asset management. This was because the BHP was a working unit within the government that was required to follow all government bureaucracies, including financial bureaucracy. In addition, it was also bound by both superior and subordinate instruction commands, which undoubtedly hindered decision-making in bankruptcy and asset management implementation.

These obstacles were addressed through the establishment of the Government Regulation in Lieu of Law (PERPPU) No. 1 of 1998 on $_{3}$ he Amendments to Law concerning Bankruptcy, in conjunction with Law No. 4 of the 1998 Government Regulation in Lieu of Law No. 1 of 1998 (hereinafter referred to as the Bankruptcy Law 1998). The Bankruptcy Law 1998 changed numerous stipulations that had held back bankruptcy settlement and blocked the management of bankruptcy assets.

Following bankruptcy law reform i1 1998, another reform was conducted in 2004 (the second period) through the issuance of Law No. 37 of 2004 on Baplruptcy \& Suspension of Debt Payment Obligation. The Bankruptcy Law 2004 revoked the previous ban 22 uptcy law, Law No. 4 of 1998, in conjunction with the Dutch Bankruptcy Regulations. The replacement of the Bankruptcy Law 1998 with the Bankruptcy Law 2004 can be considered as speedy law replacement because it was accomplished in 6 years. This is a fraction of the time it took to renew the Bankruptcy Regulations enforced in 1906, which took place nearly 100 years later in 1998 . The rapid replacement of the Bankruptcy Law expedited the bankruptcy settlement process and management of bankruptcy assets, thereby causing an increase in the EODB ranking of the bankruptcy settlement indicator. 


\subsection{The characteristics of the Indonesian Bankruptcy Law}

In the Indonesian legal system, the three nomenclatures seem to express a similar concept. Nevertheless, in ${ }_{1}$ his study, they can be distinguished based on their individual regulation contexts concerning bankruptcy, insolvency and financial distress. The bankruptcy nomenclature is used for the status of a legal subject, whether it be a natural person (natuurlijk persoon) or a law entity (rechtspersoon). Furthermore, the commercial court estaplishes that its usage extends to business entities that are not legal entities, which lose their right to control and take care of their wealth as a consequence of not paying back a loan. Bankruptcy refers to the economic context of a situation concerning the uncertainty of a company's capability to continue its operations if its financial condition worsens. Financial distress refers to financial difficulties or liquidity, which may signal the beginning of bankruptcy. ${ }^{16}$

Within the context of Indonesian law, insolvency is elated to the bankruptcy and financial distress of the debtor. On the other hand, bankruptcy may be unrelated to a bankruptcy case (law context) and the financial distress of debtors (economics context). This is because bankruptcy in Indonesia is only associated with the debtors' actions when a loan is not paid in full. David Linnan suggests that this does not require a finding of technical insolvency, which occasionally facilitates the tactical use of bankruptcy in standard commercial law dispute. ${ }^{17}$ Many things may prompt the non-payment of a loan. Sometimes, it can be caused by short-term financial distress or because the debtor's business is going bankrupt. However, it is also possible that ${ }_{1}$ the debtor is not experiencing bankruptcy or any financial difficulties; and is instead simply choosing not to make any payments. The debtor's unwillingness to pay may be done in good or in bad faith.

For example, non-payment is done in go d faith when the opposing party has not fulfilled a precondition for payment or any stipulated conditions that must be fulfilled. This was the case in the bankruptcy of PT. Telekor 1 nikasi Seluler, which was tried in the Commercial Court in Central Jakarta District Court. ${ }^{18}$ PT. Telekomunikasi Seluler stopped sending cell phone top-up vouchers to its partner, PT. Prima Jaya, because the latter was negligent in meeting performance expectations and other requirements. Similarly, the case of the petition for the Suspension of Debt Payment Obligation (PKPU) of PT. Mahkota Sentosa as in the decis 1 h of the Commercial Court in Central Jakarta District Court, ${ }^{19}$ where the company opted not to pay the bills submitted by PT. RTL and PT. ICK because they did not meet certain requirements (e.g., the authority to sign advertising cooperation contracts).

Conversely, non-payment is done in bad faith when the debtor does not make payments due to pure default. This frequently oce 1 rs in bankruptcy cases in Indonesia, such as in the case of PT. Qurnia Subur Alam Raya and PT. Central Java KSP Mandiri, which were tried in the Commercial Court in Central Jakarta District Court ${ }^{20}$ and the Commercial Court in Semarang District Court, respectively. ${ }^{21}$

The bankruptcy law polig) in the Indonesian legal system instead functions as a loan collection mechanism and not as a solution for creditors undergoing financial distress or bankruptcy. This phenomenon is different from countries such as the United States, the United Kingdom and Hong Kong, which emphasise that bankruptcy is a mechanism for assisting debtors with insolvency problems. Therefore, in these countries, a solvency test is required prior to an insolvency test. This is because bankruptcy is differentiated from sustainability. Tuula Linna has stated that: 


\section{2}

"Sustainability is not a primary purpose for insolvency proceedings, but as a part of modern business management and strategy, sustainability influences liquidation and restructuring proceedings, as well." ${ }^{22}$

In Indonesia, however, such an insolvency test is not required for 1 debtor to be declared bankrupt and any justification behind the debtor's non-payment-be it due to incompetence or unwillingness-is not taken into consideration.

This situation is similar to the bankruptcy law in the Netherlands. Peter Declercq emphasised that, in the Netherlands, bankruptcy focuses more on debtors who do not pay their debts to creditors. The state is not interested in whether the debtor is incapable of making the payment or whether he simply chooses not to despite being capable of fulfilling his financial obligations. He adds:

"A bankruptcy petition has to state the facts and circumstances that constitute prima facie evidence that the debtor has based to pay its debts. This is the case when there are at least two creditors, one of who has a claim that is due and payable and which the debtor cannot pay, refuses to pay, or simply does not pay."23

The absence of bankruptcy conditions for a state of insolvency is apparent in the provisions applied regarding the act of bankruptcy, as stipulated in Article 2 paragraph (1) in conjunction with Article 8 paragraph (4) of the Bankruptcy Law. The provision only requires that the debt be not paid in full, collectible and that at least two creditors be present. Moreover, the bankruptcy proving system is an additional requirement. Article 2 paragraph (1) in conjunction with Article 8 paragraph (4) of the Bankruptcy Law does not require the debtor's insolvency.

\section{3 | FIRST PERIOD OF BANKRUPTCY REGULATION REFORM IN 1998}

The Bankruptcy Law 1998 established a highly effective special court for handling bankruptcy petitions and disputes in a process involving the management and settlement of bankrupt assets, also known as "other claims." This special court prioritises bankruptcy cases because it handles them exclusively. The judges come together to form judge assemblies to handle cases involving those who passed the bankruptcy judge certification and have educational experience and training in the field of bankruptcy.

The effectiveness of this special court is confirmed by the incoming bankruptcy case data in comparison $5_{5}$ the situation prior to its inception. Data from the first 7 years since the establishment of the 5 -ommercial Court in the District Court of Central Jakarta indicate a remarkable increase in the number of bankruptcy petitions. From having only one or two cases annually, the establishment of a special court has certainly boosted the filing for petitions (see Table 3).

The number of bankruptcy petitions continues to rise to this day. Table 4 provides an overview of bankruptcy cases filed at the commercial courts over the past 3 years.

Based on the aforementioned data, it may be concluded that the establishment of a special bankruptcy court has encouraged interested parties to submit bankruptcy petitions.

The Bankruptcy Law 1998 changed the type of receiver, which was initially dominated by the state receiver (BHP) with the addition of individual private receivers (generally advocates and accountants) who are qualified to be appointed as such. For the first time, it allowed for 
T A B L E 3 Number of cases handled by the Commercial Court of Central Jakarta during its first 7 years of operations

\begin{tabular}{|l|l|}
\hline Year & Total incoming cases \\
\hline 1998 & 31 \\
1999 & 100 \\
\hline 2000 & 84 \\
2001 & 61 \\
\hline 2002 & 39 \\
\hline 2003 & 38 \\
\hline 2004 & 46 \\
\hline
\end{tabular}

Source: Court Data.

T A B L E 4 Bankruptcy cases throughout Indonesia from 2017 to 2019

\begin{tabular}{lll} 
Year & Total incoming cases & Commercial courts \\
2017 & 411 & Central 2 akarta, Surabaya, Semarang, Medan and Makassar \\
2018 & 353 & Central Jakarta, Surabaya, Semarang, Medan and Makassar \\
2019 & 549 & Central Jakarta, Surabaya, Semarang, Medan and Makassar \\
\hline
\end{tabular}

Source: Data from the relevant Commercial Courts.

private sector (i.e., a private bankruptcy receiver and a private voluntary debt compromise administrator) involvement and the publication of insolvency law opinion. ${ }^{24}$ This new policy also strongly encouraged interested parties to utilise bankruptcy instruments to settle unpaid debts. This condition was motivated by the fact that as the state receiver, the BHP faces numerous obstacles while managing and settling bankrupt assets. These obstacles include inadequate competencies among officials, highly complex government protocols, rigid financial regulations and bureaucracy of facilities and infrastructure and very instructive subordinate/superior bureaucracy.

Aside from the special court, these private receivers also effectively increased the number of bankruptcy petitions and accelerated the bankruptcy asset management settlement process. In general, private receivers possess the necessary competencies to perform their duties and mandatory qualifications include being an advocate or an accountant. In order to be appointed as a receiver, one must first undergo bankruptcy receiver education. Lessons are taught by experts in the field and come with high-quality material. In addition, receiver education is very exclusive, despite the considerable demand from numerous interesto professionals. It is also facilitated by a professional receiver organisation in collaboration with the Indonesian Ministry of Law and Human Rights.

Currently, only three professional bankruptcy receiver organisations are licensed by the Indonesian Ministry of Law and Human Rights to offer bankruptcy receiver edufgtion, and they are the Association of Indonesian Receivers and Administrators (AKPI), the Indonesian Bond of Receivers and Administrators (IKAPI), and the Community of Indonesian Receivers and Bankruptcy (HKPI). Starting from 2019, the annual quota of each professional organisation for receiver education participants is limited to 100 participants. Therefore, there can only be a maximum of 300 receiver education participants in a year. ${ }^{25}$ 
This narrow quota of receiver education participants implies that they must go through a very stringent selection process and that not all participants successfully graduate and become receivers. They must pass the ca 21 idate receiver selection test held by a joint committee of professional organisations and the Indonesian Ministry of Law and Human Rights. The exam is very rigorous and only half of the participants from each professional organisation pass. This illustrates just how high their standards are. The quality and competence of the receivers are crucial to the process of settling bankruptcy assets management. With qualified receivers, the management of bankruptcy assets is executed effectively and in accordance with existing laws.

The Bankruptcy Law 1998 changed the material requirements for filing a bankruptcy petition. The previous Bankruptcy Regulations required the the debtor stop paying completely, while the Bankruptcy Law 1998 does not require this. It only requires that one debt not be paid in full to at least two creditors. The changes to this condition also alter the formal proof requirements (e.g., with "simple evidence"). Such "simple evidence" may imply the fulfilment of the material requirements for a visible bankruptcy petition; thus, the judge is obliged to grant the bankruptcy petition.

The Bankruptcy Law 1998 eliminates the requirement for a condition of stopping payment from a debtor, which means that bankruptcy is used as an institution to easily make a legal subject bankrupt without considering the company's solvency and financial difficulties. The juridical argument against this proposition was thus proven. First, the provision requiring the condition of the debtor who is "in a non-payment condition" was replaced with "debt not paid in full." The provision in a "non-payment condition" means that the debtor has not paid at all or completely stops paying his debt. If the debtor still pays his debt to his creditor-even though the payment is only a small part of the debt (instalments) — the debtor is not considered to be in a non-payment condition. The philosophy behind the provision is that the non-payment condition indicates that the debtor can no longer continue his or her business due to financial difficulties, has stopped paying and is incapable of paying even a ${ }_{6}$ mall portion of his debt.

The Bankruptcy Law 1998 amended the term into "do not pay in full of at least one debt that has fallen due and can be collected." "Not paying in full" meant that the debt or instalment debt is not paid in full and is completed from the required obligation. If the debtor only pays a part of his or her obligation, he or she is then categorised as "not paying in full"; therefore, this fulfils one of the conditions for the bankruptcy petition. This provision also reveals how the Bankruptcy Law 1998 does not provide any accommodation to debtors who have problems with debt to help them restructure debt repayment schemes.

This bankruptcy requirement simplification was a new paradigm in modern bankruptcy. Classic bankruptcy theory ofte 20 equired the existence of a state of insolvency for the debtor, that is, a situation wherein the debtor's assets are insufficient to pay off all his or her debts. This implied that the debtor's liabilities far exceeded the debtor's assets. Alan Schwartz suggested that bankruptcy law was first formed to resolve the debt repayment problems of debtors who had difficulty paying their debts, while those who had a lot of collective executions and assets were claimed insufficient to pay off their debts. ${ }^{26}$ The legal framework of the Bankruptcy Law 1998 did not adhere to the concept of insolvency in a bankruptcy petition, as it did not require an insolvency test. The abolition of the bankruptcy test provided a great deal of convenience and acceleration in filing a bankruptcy petition.

The Bankruptcy Law 1998 allocated a short period for the bankruptcy petition hearing (i.e., within 30 days of registering the bankruptcy at the commercial court). This meant the judge had to come up with a decision within 30 days. The 30-day window for judges to decide on the bankruptcy cases was a revolutionary change in the justice system because civil court 
cases in the district court usually have indefinite time frames, with the average civil court case lasting over a year. Given this, bankruptcy cases could be settled with greater speed, effectiveness and efficiency. As a result, stakeholders were encouraged to take advantage of debt settlement through the bankruptcy channel rather than file claims through the ordinary civil litigation channel.

In addition to the aforementioned time window, the Bankruptcy Law 1998 also reduced the number of legal remedy steps in the bankruptcy court, where high court appeals are denied. Instead, legal remedies could be made to file a cassation or review to the Supreme Court. The abolition of an appeal in the district court significantly reduced the time and money spent on a bankruptcy settlement. Usually, settlements at an appeal level take approximately 1 year. Hence, by eliminating this, the settlement time could be greatly reduced.

The Bankruptcy Law 1998 also changed the time period for the Suspension of Debt Payment Obligations (or PKPU) from a maximum of 1.5 years plus another 1.5 -year extension (i.e., a total of 3 years or equivalent to 1,000 days) to 45 days plus a maximum extension of 270 days. This change was intended to accelerate bankruptcy settlement through debt restructuring to provide legal certainty for all stakeholders. If the restructuring negotiation does not obtain an agreement from its creditors, the debtor is immediately declared bankrupt. While debtor's bankruptcy due to the failure of reconciliation in a PKPU does not result in any cassation or judicial review by the Supreme Court, the bankruptcy decision is immediately final and binding.

This bankruptcy system that provides creditors with a choice in determining whether the debtor is reorganised or bankrupt is similar to that of the United States but different from that in Europe. According to Alan Schwartz, the bankruptcy legal system in the United States differs from that of European countries in terms of how companies experiencing financial difficulties are dealt with. If the company experiencing financial difficulties is an important one, then the system in Europe generally reacts by providing subsidies to help it get out of its predicament. In other words, the government maintains involvement with the said company. On the contrary, the United States bankruptcy system passes the problem of settling the debtor's debt payments to the market demand mechanism (i.e., the creditors). The creditor must be the one to determine whether the debt payments of a company experiencing financial difficulties should be executed through liquidation or debt reorganisation. If proven to have no further supporting funds for business activities, the company is advised to take a bankruptcy or liquidation path (Chapter 7 of the US Bankruptcy Code). ${ }^{27}$

\section{I SECOND PERIOD OF BANKRUPTCY REGULATION REFORM IN 2004}

The more detailed changes to the Bankruptcy Law 2004 are as follows: First, the Bankruptcy Law 2004 confirms the meaning of "debts" in the bankruptcy law, which are debts in the broadest sense that do not only cover the debt agreement-especially debt in banking credit agreements-but also any obligations arising from the agreement or from the law. Prior to the Bankruptcy Law 2004, there was disagreement regarding the scope of "debt" that was brought about by the two varying interpretations of academics and judges. One group believed that "debt" pertained to the debt in the form of a sum of money arising from a debt agreement. It interpreted "debt" in a narrow sense, which did not include achievements that could emerge as a result of an agreement outside the debt agreement. In the practice of the bankruptcy court, there were also some members of the Supreme Court who adhered to this narrow 
interpretation. In the case of PT. Jawa Barat Indah (apartment contractor) versus Sumeni Omar Sandjaya and Widyastuti (apartment buyers), the Supreme Court argued that, according to Article 1 of the Bankruptcy Law 1998, debt was comprised of the principal debt and its interest. ${ }^{28}$ Therefore, the debt was considered in relation to the legal relationship of lending and borrowing money or the obligation to pay a sum of money as a special form of various forms of engagement in general.

Conversely, the other group argue that what was meant by "debt" in Article 1 of the 1998 Bankruptcy Act was the obligation that must be paid as a result of the engagement. Here, "debt" was interpreted in a broader sense. The term refers to the obligations in civil law, which stipulate that liabilities or debts can either arise from the contract or the law (Article 1233 of the Civil Code). This achievement included giving something, doing something or not doing anything. Some judges in the bankruptcy court also shared this opinion. In the case of PT. Suryatata Internusa versus PT. Bank BNI Cs, ${ }^{29}$ it was decided that the cost or cost of work for a development work project arising from a job contracting agreement where the project had been completed properly was to be shouldered by the contractor. It turned out that the contractor (debtor) hat not paid the contractor in full; and the corresponding unpaid cost was considered as debt, as referred to in Article 1 of the Bankruptcy Law 1998.

Second, the Bankruptcy Law 2004 affirms that all types of creditors can apply for bankruptcy. This includes secured (separatist) creditors, preferred creditors and concurrent creditors. Previously, it was unclear whether secured creditors could file a bankruptcy petition because they already held material guarantees; therefore, it was uncertain whether they could apply for bankruptcy. In insolvency systems, a variety of creditors generally exist. These include creditors given statutory ranking; possessing a certain guarantee of payment from the assets of the insolvent company; and creditors without guarantee, relying on the surplus after distribution to preferential creditors to meet their claims. ${ }^{30}$ In fact, secured creditors are allowed to apply for bankruptcy because even though they already have material guarantees, they often do not have sufficient resources to pay off their debts. In addition, security law in Indonesia remains weak in its execution. Through the bankruptcy mechanism, the rights of secured creditors are protected in terms of the execution of collateral objects. This is because after the debtor is declared bankrupt, the secured creditor is still given 2 months to execute the collateral itself. Even if the secured creditor is not able to accomplish this within 2 months, the receiver can still execute the collateral and the sales results are prioritised to pay the debts to the respective secured creditor.

Third, the Bankruptcy Law 2004 confirms what is meant by "simple evidence" in procedural law on bankruptcy at trial. According to the Law, "facts or conditions that are simply verified" refers to the presence of two or more creditors and a situation wherein due debts and are not paid. Meanwhile, the difference in the amount of debt owed by the bankruptcy petitioners and petitioned party does not interfere with the decision on bankruptcy. "Simple evidence" is highly strategic during the bankruptcy petition trial in court. Courts often decide to reject a petition on the grounds that the proof is not simple. Such a situation brings about legal uncertainty. An example of the epurt's rejection of a bankruptcy petition on the aforementioned grounds can be observed in the decision of the Commercial Court of Central Jakarta in the case of a bankruptcy petition by Hong Kong Bank versus PT. Dock \& Shipping Kodja Bahari (Persero). ${ }^{32}$

Fourth, the Bankruptcy Law 2004 reinforces the meaning of "public interest," which is the basis for the prosecutor's office to file bankruptcy against a debtor. In the Bankruptcy Law 1998, the definition and scope of "public interest" were not established. The Bankruptcy Law 2004 affirms that "public interest" 33 pertains to the interests of the nation and/or broader 
com ${ }_{2}$ unity, such as when the debtor does the following: runs away; embezzles the assets or has debts to a state-owned enterprise or a business that collects funds from the public; has debts that come from raising funds from the broader community; does not indicate good intentions or is n cooperative in resolving the problem of debts that have fallen due, or in cases related to the public interest according to the prosecutor's office.

In the Bankruptcy Law 1998, there had been no bankruptcy cases requested by the prosecutor's office that were based on public interest concerns. After the issuance of the Bankruptcy Law 2004, there have been two bankruptcy cases submitted by the prosecutor's office based on public interest concerns. The first case was the bankruptcy of PT. Aneka Surya Agung in Lubuk Pakam, submitted by the Lubuk Pakam District Attorney's Office at the Commercial Court of Medan. ${ }^{34}$ The second case was the bankruptcy of PT. Qurnia Subur Alam Raya and Ramly Arabi in Sukabumi, submitted by the Cibadak District Prosecutor's Office at the Commercial Court of Central Jakarta. ${ }^{35}$

Fifth, the Bankruptcy Law 2004 ensures that bankruptcy petitions to debtors will not be hindered by the arbitration clause stated in the contract made by the parties. The Bankruptcy Law 1998 did not clearly define whether creditors could file a bankruptcy petition against their debtors if the agreement basis between the parties was stipulated in the arbitration clause. The absence of a regulation for this provision created legal uncertainty in its implementation. Some groups of judges rejected bankruptcy petitions submitted by creditors to debtors because the basis of the argued debt in the contract was an arbitration clause. They claimed that such cases must first be settled through an arbitration body, as in the case of PT. Trakindo Utama versus PT. Sahid Jaya International Hotel. In the Decision of the Commercial Court of Central Jakarta, there were also some judges who granted bankruptcy petitions even though the agreement between the parties was governed by arbitration clauses. ${ }^{36}$ Another similar case was that of Elizabeth Prasetya Utomo versus PT. Pacific Metrorealty. ${ }^{37}$

Sixth, the Bankruptcy Law 2004 introduces a new point, stating that creditors can also propose a PKPU. In the previous provision, only debtors could submit a PKPU, while creditors were not given the right and authority to file one against debtors. ${ }^{38}$ Giving the authority to creditors to propose a PKPU to debtors led to an increase in PKPU applications. This is because the courts accept PKPU petitions $\mathrm{m}_{2}$ re frequently than bankruptcy petitions. Data taken over a 2-year period (i.e., 2015 to 2016) at the Commercial Court in Central Jakarta District Court indicated that the total number of PKPU petitions was greater than that of bankruptcy petitions and it is steadily increasing after each year in Table 5 .

Seventh, the Bankruptcy Law 2004 introduces a new point on the involvement of secured creditors in making reconciliation decisions among creditors. In the Bankruptcy Law 1998, concurrent creditors were the only parties involved in making reconciliation decisions, leaving out secured creditors. The involvement of the latter in PKPU reconciliation is intended to ensure that the debtors agree upon the reconciliation to be carried out by the debtor. If secured creditors were not involved in the reconciliation process, then the debtor would find it difficult to carry it out, as

T A B L E 5 Total number of bankruptcy and PKPU petitions in 2015 and 2016 (2019 as comparison)

\begin{tabular}{|c|c|c|c|c|c|c|}
\hline & \multicolumn{2}{|l|}{2015} & \multicolumn{2}{|l|}{2016} & \multicolumn{2}{|l|}{2019} \\
\hline & Bankruptcy & PKPU & Bankruptcy & PKPU & Bankruptcy & PKPU \\
\hline Number of petitions & 67 cases & 107 cases & 55 cases & 145 cases & 59 cases & 277 cases \\
\hline
\end{tabular}

Source: Court Data. 
it is likely that most of the debtor's assets have been pledged to the former. In addition, the assets pledged as collateral would be difficult to use if they were still controlled by the secured creditors, and there could be a possibility that the secured creditor would execute the collateral. With their involvement, secured creditors would be bound by the legalised reconciliation. This provision is essential for debtors to continue to exist by carrying out the agreements stipulated in the reconciliation so that they can maintain their businesses in accordance with the prepared plans.

Eighth, the Bankruptcy Law 2004 also regulates bankruptcy petitions against insurance companies. The new provisions in the Bankruptcy Law 2004 determine that only the Minister of Finance is authorised to make bankruptcy petitions to insurance companies. This is because an insurance company involves the broader community in collecting corporate funds through the public sale of insurance policies. Therefore, if a creditor files a bankruptcy application for it at any time, this would be detrimental to the people who have availed of an insurance policy. Large insurance company bankruptcy has occurred in Indonesia; for instance, PT. Manulife Indonesia Life Insurance had filed for bankruptcy through one of its creditors and was sentenced to bankruptcy by the Commercial Court of Central Jakarta. ${ }^{39}$ However, the bankruptcy decision of PT. Manulife Indonesia Life Insurance was later cancelled by the Supreme Court. ${ }^{40}$ Similarly, a credito 2 of the insurance company PT. Prudential Life Assurance filed a petition for bankruptcy and it was declared bankrupt by the Commercial Court of Central Jakarta. ${ }^{41}$ Likewise, the bankruptcy decision was later cancelled by the Supreme Court. ${ }^{42}$

\section{5 | THE NEED FOR A THIRD PERIOD OF BANKRUPTCY POLICY REVISION TO FURTHER INCREASE THE EODB RANKING}

Although the bankruptcy settlement indicator ranked higher in the EODB 2019, reaching 67.89 points and taking the 36th position worldwide; considering Indonesia's 2019 EODB ranking being the 73rd, (see Table 6) further revisions to the Bankruptcy Law are still necessary so that the bankruptcy settlement indicator and rank scores can increase, thereby increasing Indonesia's overall EODB ranking. The revised Bankruptcy Law will refer to the parameters set by the World Bank, which are associated with the completion indicator of bankruptcy, namely management and settlement period of bankruptcy assets, the cost required for the management and settlement of bankruptcy assets, the recovery rate of creditor's receivables and the strength of the insolvency framework index.

There are several points to revise from the Bankruptcy Law 2004. First, it is necessary to amend provisions related to the period acceleration of bankruptcy management and settlement. The time window under the current Bankruptcy Law only considers the bankruptcy petition process requiring the judge to make a decision within 60 days. However, after the bankruptcy decision is pronounced, the next stage involves the management and settlement of the bankruptcy assets carried out by the receiver under the supervision of the supervisory judges. This

\begin{tabular}{|lll|}
\hline & $\mathbf{2 0 1 8}$ & $\mathbf{2 0 1 9}$ \\
\hline EODB rank & 72 & 73 \\
\hline EODB score & 66.47 & 67.96 \\
\hline
\end{tabular}

TAB LE 6 Indonesian EODB overall ranking and score in 2018 and 2019

Source: World Bank. 
stage has no time limit. The absence of a deadline for the settlement of bankruptcy assets after the debtor is declared bankrupt has caused legal uncertainty for interested parties, especially creditors. An example of this issue is $P T$. Interkon $\mathrm{K}_{26}$ n Jeruk, which the court declared bankrupt in 1999 through the Verdict of the Commercial Court of Central Jakarta. ${ }^{43}$ The bankruptcy management of PT. Kebun Jeruk has not been completed to date.

With respect to the necessary revision of the time frame for the settlement of bankrupt assets, the first necessary step involves making a copy of the bankruptcy decision that must be given to all relevant parties (e.g., debtors, creditors and supervisory judges) after being pronounced within three to five working days. In practice, what usually happens is that the receiver does not receive a copy of the bankruptcy decision, even after a long period of time. Thus, the receiver cannot immediately begin conducting the assignment. Second, the receiver must define the limitations on the completion of the list of bankrupt assets. Third, a time window must be set for the claim settlement, lawsuit settlement for the actio pauliana, and lawsuit completion for the renvoi procedure. ${ }^{44}$ Fourth, the limit on insolvency determination should be stipulated at the latest period by the supervisory judge. Insolvency determination is a pivotal phase in the process, considering that bankruptcy and subsequent bankruptcy assets distribution to creditors begin after the bankruptcy settlement. Thus, if the insolvency determination is prolonged and not clearly established, this would disrupt the consequent implementation and division of bankruptcy assets. It is also necessary to regulate the need for receivers to notify secured creditors regarding the establishment of insolvency so that the latter can make full use of their time to carry out their own execution of collateral within 2 months of insolvency determination.

The second step requires the Bankruptcy Law to provide secured creditors with sufficient time to execute their collateral goods. The Bankruptcy Law 2004 stipulates that secured creditors are allowed to execute the collateral goods they hold within 2 months of the bankruptcy settlement. This 2-month period is deemed insufficient because the execution of the material guarantee requires a public auction conducted by the state auction office, and this may take some time to accomplish. Moreover, one auction would not be sufficient in order to successfully carry out the auction with buyers present. Realistically speaking, a minimum of three auctions is required to provide a fair opportunity for the secured creditors holding the collateral guarantee. The duration required to execute collateral objects for secured creditors should be at least four to 6 months. Most secured creditors come from the banking sector. With adequate execution, the recovery rate can increasingly be maximised. In addition, banking is one of the important pillars of an economic turnaround.

Providing secured creditors with sufficient time to execute collateral objects is in accordance with the bankruptcy theory and the creditors' bargain theory. Ayotte and Skeel stated that the creditors' bargain theory has two key elements. ${ }^{45}$ The first element is the principle of efficiency, as the main purpose of filing for bankruptcy is to increase the acquisition value of bankruptcy assets as well as restore the debtors' and creditors' conditions. The second element is the Normative Butner Principle, which holds that new concurrent creditors hold the right to receive payments from the secured creditors' remaining collaterals upon the latter's receipt of full payment and once the preferential creditors are also paid.

The third step is for the Bankruptcy Law to confirm bankruptcy completion of corporate debtors with legal entities. The receiver must then submit all documents to the bankrupt debtor and subsequently become the debtor's bankruptcy authority that determines whether the corporation will be shut down or continue its operations. As economic owners of a company, shareholders also need to protect their interests. ${ }^{46}$ This is especially important because EODB 
assesses the business continuation for debtors who have settled bankruptcy assets to contribute added value to the business world. Currently, conflicting rules exist ${ }_{14}$ tween the Bankruptcy Law (Law No. 37 of 2004) and the Limited Liability Company Law (Law No. 40 of 2007). The Limited Liability Company Law stipulates that if a company is declared insolvent in bankruptcy, the limited liability company must be dissolved. On the other hand, the Bankruptcy Law stipulates that bankrupt debtors that declare insolvency are not dissolved. Rehabilitation can be carried out, reconciliation can be achieved and even though the debt was past due, bankruptcy can be revoked to return to normalcy.

The arrangements specified in the Limited Liability Company Law have the potential to exacerbate the investment climate of Indonesia because the World Bank's EODB assessment covers how a company that has gone bankrupt and completed the distribution of bankruptcy assets, can rerun its business, either through reconciliation or through the restoration of their rights. The Bankruptcy Law provisions are actually in accordance with those of the World Bank, where after bankruptcy ends, all of the receiver's documents and records are given to the bankrupt debtor. It then becomes the bankrupt debtor's decision whether to submit a request for rehabilitation to court, to resume normal operations, or to shut down the company entirely. This is in line with the purpyge of bankruptcy as a legal instrument to liquidate the insolvent debtor's assets, which are to be distributed to the creditors. Upon completion of the distribution of assets, the bankruptcy mechanism is also completed and the debtors may subsequently return to normal.

The fourth step will involve the provisions governing the maximisation of bankruptcy assets being regulated in greater detail in the revision of the Bankruptcy Law. By maximising the number of bankrupt assets, the recovery rate of creditors' receivables will increase; thus providing creditors with certainty regarding the return of their debts from debtors. One measure that can maximise the number of bankrupt assets is the implementation of sanctions against bankrupt debtors who hide bankruptcy assets. This sanction is needed because the receiver often faces issues while managing bankruptcy assets, which includes accessing bankrupt debtor assets in the form of both bank accounts and property assets. In regard to this sanction, it is necessary to affirm such forced implementation (hostage) for bankruptcy uncooperative debtors. The point on the detention of non-cooperative bankrupt debtors in the Bankruptcy Law 2004 was regulated in connection with bankruptcy asset management. However, the arrangement is still vague and cannot be implemented. To date, not a single court decision has granted a detention request against non-cooperative bankrupt debtors in connection with the management and settlement of bankrupt assets.

Another point associated with bankruptcy asset security is the need for authority regulation for receivers to file a ban (prevented detention) against bankrupt debtors who intend to flee abroad. This disrupts the necessary coordination between the receiver and debtor during the management of the bankruptcy assets. It is important for the debtor to be physically present during bankruptcy management procedures (e.g., in meetings about the verification of the receivable account, bankruptcy assets, and reconciliation plan). Furthermore, in the context of 1 ase Number 138/Pdt.Sus.PKPU/2016.PN.Niaga.Jkt.Pst, the bankruptcy respondent $\frac{2}{w}$ as declared bankrupt by the court. Since there was no reconciliation over the PKPU, the bankrupt debtors fled to Singapore, making it difficult for receivers who were in the process of managing and settling the bankruptcy assets.

The provisions that govern the maximisation of bankruptcy assets are also in accordance with the creditors' bargain theory. According to Thomas Jackson, in order to avoid common pool conditions in bankruptcy, bankrupt asset management efficiency must be improved by 
T A B L E 7 Bankruptcy settlement ranking 2018 and 2019

\begin{tabular}{|lcr|}
\hline Indicators & $\mathbf{2 0 1 8}$ & $\mathbf{2 0 1 9}$ \\
\hline World ranking for resolving insolvency/bankruptcy settlement & 38 & 36 \\
\hline Score for resolving insolvency/bankruptcy settlement (0-100) & 67.1 & 67.9 \\
\hline Time (years) & 1.1 & 1.1 \\
\hline Cost (\% of assets) & 21.6 & 21.6 \\
\hline Recovery rate (cents on the dollar) & 64.7 & 65.2 \\
\hline Strength of insolvency framework index (0-16) & 10.5 & 10.5 \\
\hline
\end{tabular}

Source: World Bank.

focusing primarily on accumulating the value of bankrupt assets and simultaneously reducing bankruptcy costs in the manner agreed upon by the creditors. For this purpose, bankruptcy law-as a collective debt payment instrument-should ideally be geared towards providing maximum payment to each creditor by making the best efforts that can be applied to bankruptcy assets. ${ }^{47}$

\section{6 | CONCLUSION AND RECOMMENDATION}

Indonesia has succeeded in conducting bankruptcy-related policy reforms, causing several bankruptcy petitions to be decided by the court and the end of a bankruptcy settlement. Bankruptcy policy reform in Indonesia $\sigma_{3}$ curred twice: first in 1998 with the issuance of Law Number 4 of 1998, in conjunction with Government Regulation in Lieu of Law Number 1 of 1998, and then in 2004 with the issuance of Law Number 37 of 2004.

The success of bankruptcy policy reform has also led to an increase in Indonesia's EODB rating, which includes the settlement of bankruptcy cases as an indicator. Indonesia's EODB ranking rose rapidly from being at 129th position in 2012 to 73 rd in 2019. Of the 10 EODB indicators, the bankruptcy settlement indicator played a very significant role, with Indonesia's bank settlement ranking reaching 36th position worldwide in 2019 (see Table 7). Therefore, many lessons can be learned from bankruptcy policy reform in Indonesia.

Although the bankruptcy policy reform has benefited Indonesia's EODB, it remains necessary to undergo a third period of reform so that bankruptcy settlement can be even more progressive in the future. The areas that should be amended include: time acceleration for bankruptcy management, sufficient time provision for secured creditors to execute their collateral, bankruptcy termination that does not automatically dissolve legal entities and the regulations that support the maximisation of bankrupt assets.

\section{ENDNOTES}

${ }^{1}$ Darminto Hartono, "Debtor and Creditor Leaming: Changes over Time in Indonesian Bankruptcy Reorganization Approaches" in David Linnan (ed), Legitimacy, Legal Development, and Change: Law and Modernization Reconsidered (Ashgate 2012), 106.

${ }^{2}$ Philippe Nonet and Philip Selznick, Law and Society in Transition: Toward Responsive Law (Harper \& Row, 2008), 14. 
${ }^{3}$ The new order was the government under President Suharto from 1967 to 1998, during which time the law enacted was repressive.

${ }^{4}$ The old order was the government under President Sukarno from 1945 to 1966, where the law enacted was equally repressive.

${ }^{5}$ Roman Tomasic et al., 'Insolvency Law Administration and Culture in Six Asian Legal Systems' [1996] 6 Australian Journal of Corporate Law 258.

${ }^{6}$ David Linnan, "Insolvency Law and Institutions in Indonesia" in Roman Tomasic (ed), Insolvency Law in East Asia (Ashgate 2006), 355.

${ }^{7}$ Stacey Steele, "The New Law on Bankruptcy in Indonesia: Towards a Modern Corporate Bankruptcy Regime?" [1996] 23(1) Melbourne University Law Review 144.

8 ibid, 107 .

${ }^{9}$ Data were taken from five commercial courts located in Central Jakarta, Surabaya, Semarang, Makassar, and Medan.

${ }^{10}$ Majallah Pusat Pengkajian Hukum [Legal Review Centre Newsletter] No. 69 Juni 2007, hlm. 3334.

${ }^{11}$ ibid, 144.

${ }^{12}$ Pauzi Yusro, "Receiver and Official Education Forum based on the Bankruptcy Law" (Interview by author, 2000).

${ }^{13}$ Munir Fuady, Hukum Pailit dalam Teori dan Praktik [Bankruptcy Law in Theory and Practice] (Citra Aditya Bakti, 2005), 1.

${ }^{14}$ Delivered at the Bankruptcy Law Seminar (Surabaya, 23 March 2000).

${ }^{15}$ Sudargo Gautama, Komentar atas Peraturan Kepailitan Baru untuk Indonesia [Commentary on New Bankruptcy Regulations for Indonesia] (Citra Aditya Bakti, 1998), 2.

${ }^{16}$ M. Hadi Shubhan, "The Utilization of Unwritten Laws in Bankruptcy Disputes" (2019) 8(1) Journal of Rechtsvinding 88.

${ }^{17}$ ibid, 362.

${ }^{18}$ Case Number 48/PAILIT/2012/PN.NLAGA.JKT.PST in conjunction with the Cassation Decision Number 704K/ Pdt.Sus/2012. Data obtained from the Commercial Court of Central Jakarta.

${ }^{19}$ Case Number 68/Pdt.Sus/PKPU/2018/PN.Niaga.Jkt.Pst.

${ }^{20}$ Case Number 09/Pdt.Sus/Pailit/2013/PN.NIAGA.JKT.PST. Data obtained from the Commercial Court of Central Jakarta.

${ }^{21}$ Case Number 13/Pdt.Sus-Pailit/2018/PN Niaga Smg in conjunction with 7/Pdt.Sus-PKPU/2016/PN Smg. Data obtained from the Commercial Court of Semarang.

${ }^{22}$ Tuula Linna, "Insolvency Proceedings from a Sustainability Perspective" (2019) 28 Int Insolv Rev. 210.

${ }^{23}$ Peter Declercq, Netherlands Insolvency Law, the Netherlands Bankruptcy Act and the Most Important Legal Concept (T.M.C. Asser Press, 2002), 63.

${ }^{24}$ Soogeun Oh, "Comparative Overview of Asian Insolvency Reforms in The Last Decade" (2006), based on a report delivered by Mr. Soogeun Oh to the Fifth Forum for Asian Insolvency Reform (FAIR), which was held on April 27-28, 2006 in Beijing, China.

${ }^{25}$ The number of private receivers registered up to 2019 is 4,987 .

${ }^{26}$ Alan Schwartz, "A Normative Theory of Business Bankruptcy" (2005) 91 Virginia Law Review 1200.

${ }^{27}$ Ibid., 1205-1206.

${ }^{28}$ Case Number 05 PK/N/1999.

${ }^{29}$ Case Number $08 \mathrm{PK} / \mathrm{N} / 1999$.

${ }^{30}$ Paul Omar, "The Landscape of International Insolvency Law" (2002) 11 International Insolvency Review 175.

${ }^{31}$ Article 8, paragraph 4, Bankruptcy Law 2004. 
${ }^{32}$ Case Number 32/Pailit/2000/PN.Niaga/Jkt.Pst; Supreme Court Cassation Number 21K/N/2000.

${ }^{33}$ Article 2(2), Bankruptcy Law 2004.

${ }^{34}$ Case Number 02/Pailit/2005/PN. Niaga/Medan.

${ }^{35}$ Case Number 23/Pdt.Sus/Pailit/2013/PN.Niaga/Jkt.Pst.

${ }^{36}$ Case Number 80/Pailit/2000/PN.Niaga/Jkt.Pst; Supreme Court Decision Number 05 K/N/2001; Supreme Court Number $10 \mathrm{PK} / \mathrm{N} / 2001$.

${ }^{37}$ Supreme Court Number $1 \mathrm{~K} / \mathrm{N} / 2004$.

${ }^{38}$ Article 212(1), Bankruptcy Law 1998.

${ }^{39}$ Case Number 10/PAILIT/2002/PN.NIAGA.JKT.PST.

${ }^{40}$ Supreme Court Decision Number $21 K / N / 2002$.

${ }^{41}$ Case Number 13/Pailit/2004/PN.Niaga.Jkt.Pst.

${ }^{42}$ Supreme Court Decision Number $08 \mathrm{~K} / \mathrm{N} / 2004$.

${ }^{43}$ Case Number 31/Pailit/1999/PN.Niaga.Jk.Pst; Supreme Court Number 20K/N/1999 and Number 019 PK/N/1999.

${ }^{44} \mathrm{Renvoi}$ procedure is a legal remedy conducted by the debtor or creditor in response to disagreement on the amount of debt.

${ }^{45}$ Kenneth Ayotte and David Skeel Jr., "Bankruptcy Law as a Liquidity Provider" (2013) 80(4) University of Chicago Law Review 447.

${ }^{46}$ David Korobkin, "Rehabilitating Values: A Jurisprudence of Bankruptcy" (1991) 91 Columbia Law Review 717.

${ }^{47}$ Thomas Jackson, The Logic and Limits of Bankruptcy Law (Harvard University Press, 1986), 1-2.

How to cite this article: Shubhan $\mathrm{MH}$. The effects of reforming regulatign in resolving insolvency towards EODB rank improvement: Evidence from Indonesia. Int Insolv Rev. 2020;1-17. https://doi.org/10.1002/iir.1372 
The effects of reforming regulation in resolving insolvency towards EODB rank improvement: Evidence from Indonesia

ORIGINALITY REPORT

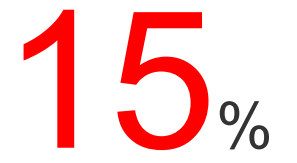

SIMILARITY INDEX

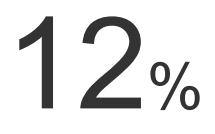

INTERNET SOURCES

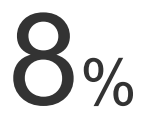

PUBLICATIONS
$0 \%$

STUDENT PAPERS

PRIMARY SOURCES

1 www.rechtsvinding.bphn.go.id

2 M. Hadi Shubhan, Indrawati, Dri Utari CR.

"LEGAL RESTRICTION OF BANKRUPTCY

OF STATE-OWNED ENTERPRISE (SEO)

AND SUSTAINABILITY: THE CASE OF

INDONESIA", Humanities \& Social Sciences

Reviews, 2020

Publication

3 www.austlii.edu.au

4 Wisnu Cahyono, Wahyu Haris Kusuma

Atmaja, Asteria Palupi Karyuniati.

"Digitalization Solution on Customer Services

to Leverage the Ease of Getting Electricity",

2019 International Conference on

Technologies and Policies in Electric Power \&

Energy, 2019

Publication

Gustaaf Reerink, Kevin Omar Sidharta, Aria

Suyudi, Sophie Hewitt. "8 The Commercial 
Courts", Cambridge University Press (CUP), 2019

Publication

6 WwW.shs-conferences.org

7 Catarina Frade, Paula Fernando, Ana Filipa Conceição. "The performance of the courts in the digital era: The case of insolvency and restructuring proceedings", International Insolvency Review, 2020

Publication

8 eodb.ekon.go.id

9 slidelegend.com

10 "Issue Information", International Insolvency Review, 2020

11 thelawreviews.co.uk

12 librarysearch.aut.ac.nz 
15 corporate social responsibility in Indonesia", The Pacific Review, 2010

16 Sharyn Graham Davies, Jazz Robson.

"Juvenile (In)justice: Children in Conflict with

the Law in Indonesia", Asia-Pacific Journal on

Human Rights and the Law, 2016

Publication

17 studylib.net

19 Tuula Linna. "Insolvency proceedings from a sustainability perspective", International Insolvency Review, 2019

Publication

20 core.ac.uk

21 Edwin Jurriëns. "Intertwined Ecologies", Third Text, 2018

22 docplayer.net 


\section{Submitted to Universitas Airlangga}

Exclude bibliography On 